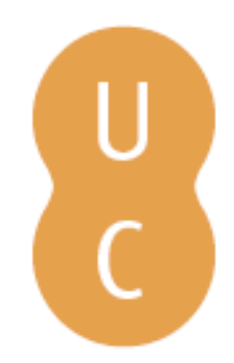

\title{
nombalina
}

\section{The place of Plutarch in the literary genre of Symposium}

\author{
Autor(es): $\quad$ Teodorsson, Sven-Tage
}

Publicado por: Imprensa da Universidade de Coimbra; Centro de Estudos Clássicos e

URL

persistente: URI:http://hdl.handle.net/10316.2/31970

DOI: $\quad$ DOI:http://dx.doi.org/10.14195/978-989-8281-17-3_1

Accessed : $\quad$ 26-Apr-2023 10:36:25

A navegação consulta e descarregamento dos títulos inseridos nas Bibliotecas Digitais UC Digitalis, UC Pombalina e UC Impactum, pressupõem a aceitação plena e sem reservas dos Termos e Condições de Uso destas Bibliotecas Digitais, disponíveis em https://digitalis.uc.pt/pt-pt/termos.

Conforme exposto nos referidos Termos e Condições de Uso, o descarregamento de títulos de acesso restrito requer uma licença válida de autorização devendo o utilizador aceder ao(s) documento(s) a partir de um endereço de IP da instituição detentora da supramencionada licença.

Ao utilizador é apenas permitido o descarregamento para uso pessoal, pelo que o emprego do(s) título(s) descarregado(s) para outro fim, designadamente comercial, carece de autorização do respetivo autor ou editor da obra.

Na medida em que todas as obras da UC Digitalis se encontram protegidas pelo Código do Direito de Autor e Direitos Conexos e demais legislação aplicável, toda a cópia, parcial ou total, deste documento, nos casos em que é legalmente admitida, deverá conter ou fazer-se acompanhar por este aviso.

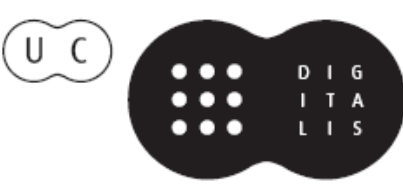




\section{Symposion and Philanthropia in Plutarch}

\section{José Ribeiro Ferreira, Delfim Leão Manuel Troster e Paula Barata Dias (eds.)}

IMPRENSA DA UNIVERSIDADE DE COIMBRA 


\title{
The Place of Plutarch in the literary genre of Symposium
}

\author{
Sven-Tage Teodorsson \\ Göteborg University
}

\begin{abstract}
Plato's idea to have a dialogue on serious philosophy taking place at a drinking-party is actually astonishing, considering the traditionally rather "unphilosophic" entourage of these feasts. His Symposion covers a vast scope extending from the most subtle philosophic reasoning of Socrates to the final deranged, unrestrained drinking-bout. In spite of this vulgar ending, however, the work is basically a philosophic dialogue. That this work happened to form the starting-point of a new literary genre, the symposion, may have been largely due to Xenophon. Many more contemporary and somewhat later writers produced works of the kind, but all are lost. Since the third century B.C. the Cynic Menippean sympotic genre became prevalent instead of the philosophic Socratic one, which, as far as we know, is totally absent until Plutarch revived it with his Sept. sap. conv. In addition he created a new subgenre of sympotic writing, the Quaestiones convivales. He probably wrote his convivial works in opposition to the Menippean kind. His evident ethical and educational purpose is singular in the genre of symposion; he received no followers.
\end{abstract}

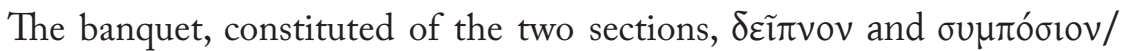

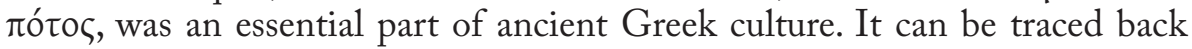
as far as Homer ${ }^{1}$, and during the Archaic period the sympotic customs were established in a regular, almost ritualized form, the aristocratic $\sigma u \mu \pi$ ó This was an institution for the upper classes, and it had its place in the courts of kings and tyrants and in the $\alpha v \delta \rho \tilde{\omega} v \varepsilon \zeta$ of citizens in prominent position. The symposion was an integrated part of life of the political and military clubs, the aristocratic É $\tau \alpha \iota p \varepsilon \tilde{\imath} \alpha$. These circles of educated and well-to-do people was a natural environment for song, music, dance and recitation, which inspired poets to the lavish productions of the archaic lyric and choral poetry, not least the so-called scolia, and painters got abundant motives for vase paintings. Artists of different profession, such as musicians, dancers, actors, acrobats and merry-makers, were often engaged by the host, but the guests themselves also took on large parts of the entertainment. The well-known competitive spirit of the Greek society found a natural arena in the symposion. There were competitions in song and music, or in solving riddles and other problems. A demand was laid on the symposiasts that each in turn should sing a song accompanying himself with the lyre. For such performances a formal musical education was presupposed. In the Archaic age all participants at symposia had acquired the necessary competence. But towards the end of the sixth century the great changes in the political state of things in Athens also brought about changes in the character of the symposion. The conventional educational system was modified, new groups of citizens advanced to power, and after the Persian wars the living standards of the population rose. The institution of the symposion received a more luxurious, and also more private and varied

\footnotetext{
${ }^{1}$ Il. $1.595-604 ; 9.197-224$.
} 
character, different from the conventionally regulated, aristocratic archaic symposion. Plutarch tells of an incident that gives a notion of the easy manners in the symposion of the Classical time. In the Life of Cimon he reports that Themistocles once frankly declared that he had not learnt to sing, nor to play the lyre, but that he knew how to make the city great and rich $^{2}$. In the course of time the ability to play the lyre declined, and recital gradually replaced singing. ${ }^{3}$. As a consequence, less exacting activities filled larger parts of the sympotic program, such as competitions of easy, banal kind, informal singing and dancing ${ }^{4}$, merry-making and, above all, heavy drinking, either freely or as a contest performed serially around the company. The $\kappa \tilde{\omega} \mu \circ \zeta_{\text {became more }}$ important as an ostentatious display of drunkenness ${ }^{5}$. The change from the symposion of the Archaic age into that of the period of democracy can be studied in the motives of vase paintings of the time ${ }^{6}$.

The symposion was in itself always aimed at pleasure. It offered the opportunity of relaxation and permitted, or occasionally rather imposed upon, the revellers to drink abundant quantities of wine, and thus to indulge in misbehaviour and quite unbridled licence of erotic or violent kind. The vase paintings offer abundant evidence, and indications can also be found in literature ${ }^{7}$. It was therefore entirely to be expected that Plato should adopt a negative attitude towards symposia. In the dialogues Socrates never fails to repudiate the heavy drinking that ran rampant at the contemporary symposia, together with everything else that occupied $i t^{8}$. He disdains listening to the equivocal witticisms of the jesters and he scorns the customary riddles and puzzles that occupy ordinary people's minds at the drinking-parties; he compares them with children's riddles'. It is Plato's conviction that philosophers can have nothing in common with ordinary men. Enjoying drinking-parties is not part of a philosopher's $\pi \alpha 1 \delta \varepsilon i ́ \alpha$. In the Theaetetus Plato's Socrates draws a very clear line of demarcation between the philosophers and the people of the city who are busy with their politics and their symposia. Both should be strictly avoided. Socrates says: "These meetings and banquets and revellings with chorus girls, it never occurs to the philosophers even in their dreams to indulge in such things." ${ }^{10}$.

${ }^{2}$ Ion ap. Plu., Cim. 9.1; cf. Them. 2.3-4.

${ }^{3}$ Cf. S.-T. Teodorsson, 1989, pp. 59-63.

${ }^{4}$ At X., Smp. 7.1-2 Socrates improvises a song.

${ }^{5}$ This behaviour was prevalent both in the upper classes and among common people, cf. the

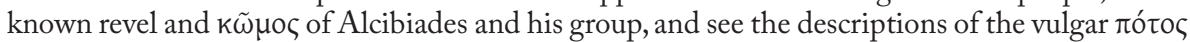
in Ar., V. 1208-1537. See also F. Frazier, 2000.

${ }^{6}$ See J. N. Bremmer, 1990, pp. 144-5, with a vast bibliography on the subject.

${ }^{7}$ See, e.g., F. Lissarague, 1982, and cf. Ath. 13.577 E-F. 579 A, D, 607 CD.

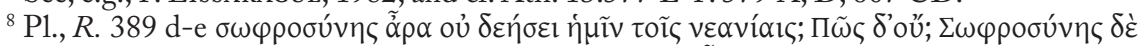

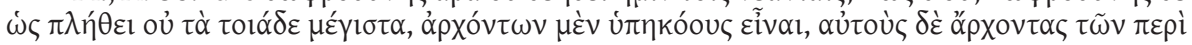

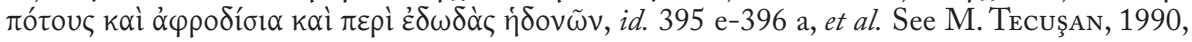
pp. 238-43. 143-4.

${ }^{9}$ R. 479 b-c. For the nature of the riddles and puzzles see S.-T. Teodorsson, 1990, pp.

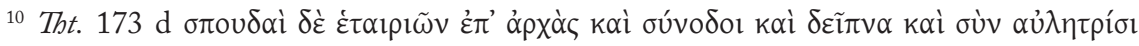


Plato held these views nearly all his life. However, in his old age he changed his mind. He abandoned his negative, reluctant attitude and advocated a moderated and controlled use of wine as an integrated part of the $\pi \alpha i \delta \varepsilon i ́ \alpha$. As is well known he devoted the first two books of the Laws to a lengthy discussion on symposia, wine and drunkenness. He denounces practically all the symposia of his time as totally deranged and presents a reform program. He argues that symposia, wine and intoxication can and should be used as a means of education. For example, intoxication can be used for testing the $\alpha \rho \varepsilon \tau \eta^{11}$. This awareness of the revealing effect of the wine was not new; for example, it can be found in Alcaeus, Aeschylus and Ion of $\mathrm{Chios}^{12}$.

\section{Plato's Symposium}

Now, I would like to suggest that this was exactly what Plato had in mind when he decided to locate his important dialogue on Eros in the sympotic entourage. He wanted to demonstrate the ideal $\alpha \rho \varepsilon \tau \eta$ of Socrates, both his sublime $\sigma \omega \varphi \rho \circ \sigma u ́ v \eta$ and self-control concerning carnal love-passion, and his ability to withstand the negative effects of intoxication.

It is noticeable that in reporting the course of events of his Symposium Plato describes everything as decent and orderly. This was probably how the gatherings in the Academy were carried out under his guidance, in a decorous way and characterized by intellectual conversations, though not entirely sober. This kind of drinking-party Plato wanted to present to his readers when he wrote his Symposium, and it was of course the condition necessary for a proper philosophical dialogue, as is announced at the beginning, when the flute-girls are dismissed, and drinking is inhibited.

After Socrates has finished his sublime speech, the spell is suddenly broken when Alcibiades and his band rush in and bring about an abrupt change in the lofty philosophic atmosphere. The time has now come for the test of Socrates' virtue. Alcibiades' detailed report of Socrates power of resistance to his efforts of seduction is substituted for a scene of that sort in real time at the party, and then the final drinking-bout displays Socrates as the victor in this test also.

Plato's Symposium is obviously far from being a representation of a real banquet. His aim was entirely philosophic, to bring out the philosophic Eros in full relief, incarnated in the person of Socrates, as contrasted with

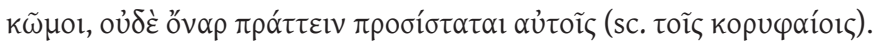

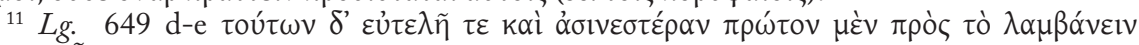

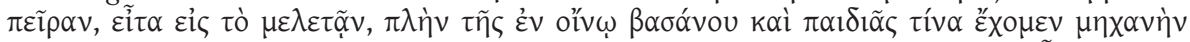

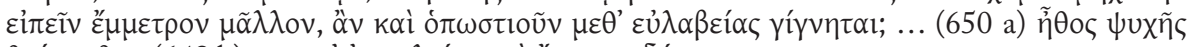

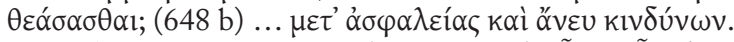

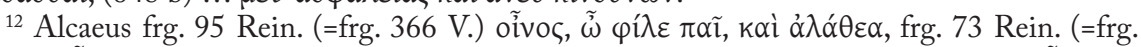

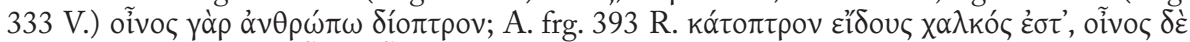

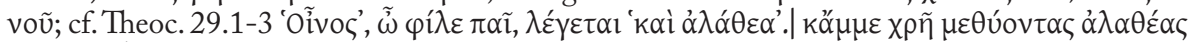

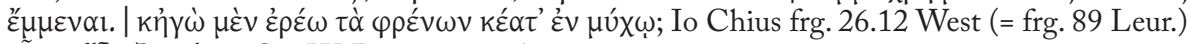

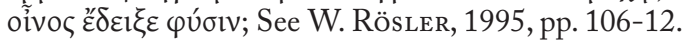


the inferior one of Alcibiades. Although Plato delusively makes efforts to depict the scenery in realistic terms, the work comes out as a product of Plato's imagination in order to present his philosophic message. ${ }^{13}$

\section{Xenophon's Symposium}

With his Symposium Plato founded a literary genre that was to live on throughout antiquity and even further. It was no doubt thanks to the figure of Socrates that there was a sequel at all. It was the figure of Socrates that inspired Xenophon with the idea to write a similar work. But of course he had no intention to emulate Plato. He had no motive for treating any philosophical problem; his intention was simply to tell his readers what it was like to spend a night at a drinking-party in company with Socrates. He wanted to represent his friend in the role of a symposiast taking part in the conversation and the entertainments of a conventional banquet. He declares his purpose directly in the first sentence, where he states that according to his opinion it is worth while to report the deeds of Socrates even in times of relaxation. In fact, Xenophon's Symposium might be regarded as a separate addition to the Memorabilia ${ }^{14}$, written in order to complete the picture of the figure of Socrates. Just as in that work he most probably had the ambition to represent him in a realistic and thrustworthy way.

I called Xenophon's Symposium a conventional one. That is true as regards the unconstrained variation of ingredients. The alternation between entertainment and more of less serious conversation gives a seemingly realistic picture of a normal banquetal scene. However, if Plato's sweeping description of the drinking-parties of the time as totally deranged was true to reality, it would mean that the party reported by Xenophon was also exceptional, just as that of Plato. There are no erotic indecencies, and when Philippus the jester, exhausted after having performed a tiring dance, asks for a big cup of wine, and Callias the host gladly agrees and says that all are thirsty from laughing at him, Socrates intervenes. He calls for caution and gives a short lecture on the proper use of wine, in the shape of a simile. Just as plants are thrown to the ground and cannot produce fruit, when Zeus pours too much rain on them, so it is with us: if we drink a lot of wine at once, both body and soul will stagger, and we will be unable to say anything of value. And Socrates proposes that the attending boys should besprinkle the company with small drops only. Everyone agrees to the proposal, although Philippus the jester wants the boys to fill up the cups faster ${ }^{15}$. After that, nothing is said about wine $e^{16}$, and there is no final drinking-bout. This agreement, a result of the intervention of Socrates, announces the mode of behaviour that

${ }^{13}$ See D. Babut, 1980.

${ }^{14}$ This was the opinion of J. Martin, 1931, pp. 177-8 (following Ullrich).

${ }^{15}$ See Ch. 2. 23-27.

16 At Ch. 6. 2 Hermogenes answers Socrates' question, what unconvivial behaviour ( $\pi \alpha \rho o$ ví́ $\alpha$ ) is: "To give pain to one's companions under the influence of wine". 
is to characterize the party, namely a decorous social intercourse under his unobtrusive guidance.

As in Plato's Symposium, Socrates had hesitated to accept the invitation to the banquet. The rich Callias, who is paying large sums of money to Protagoras for wisdom, seemed to him not to be the host to his taste. Xenophon describes the feeling during dinner as quite depressed, with the guests feasting in deep silence as though ordered to do so by some authority (I.11). Not even Philippus the jester was able to cheer up the company.

After dinner, however, the atmosphere changes as Socrates gradually takes the lead. He politely praises Callias for the perfect dinner and the performance of the young artists, but when the host also offers perfume, he declines and takes the chance of making some philosophic reflections on fragrances. In his view, there is no need of perfumes at all. Young men who excercise in the gymnasium should smell of olive oil, and women smell of perfume themselves. Elderly men, however, should smell of $k \alpha \lambda$ ok $\alpha \gamma \alpha \theta i ́ \alpha$.

When Socrates had thus broken the ice and a lively discussion had arisen, we would expect that he should go on philosophizing. He does not; instead he himself proposes to postpone conversation until a second performance has been given by the young dancers and acrobats. After this he makes some remarks on their achievements and observes that women can very well be educated and even learn courage. By such little sophisticated comments Socrates determines the intellectual level of the conversation. The result is an exchange of views and opinions of rather poor substance.

Now Socrates proposes that the symposiasts should themselves try to benefit and delight each other, and it is decided that each person should speak about what he considers himself good at and is pride of. What follows is a multifarious conversation more or less guided by Socrates. It is notable that during these discussions he often exposes himself to irony and teasing, while he is also ironic himself. Nevertheless the atmosphere is almost unchangingly pleasant and friendly.

Of course we cannot judge whether Xenophon describes Socrates truly or not, but in fact he makes us believe that he was really such a highly amiable, humorous and concilatory man. In any case, Xenophon represents him as extraordinary able to bring about an orderly and friendly symposion. As to the intellectual standards of the subjects he initiates, however, we may doubt whether Xenophon does him justice. Most of the talk on the various subjects during the conversation that extends over four chapters (3-6) is rather nugatory. Only the speech of Antisthenes on his poverty, which he calls wealth, is of a certain philosophic value. But Xenophon is apparently satisfied with the conversation and remarks (IV 29): "In this way they mixed playful and serious."

After this mixed, partly trivial conversation Xenophon makes Socrates finish off the discussion with a long speech, very clearly following the lead of Plato's Symposium. It would seem that Xenophon felt obliged somehow to make Socrates appear in his role as "thinker", though at a not to sophisticated level. The theme is arguably Eros, but since he was probably not able to represent 


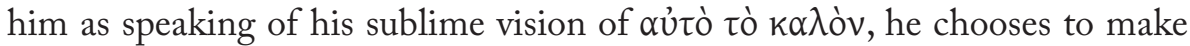
him speak on the basis of the speech of Pausanias in Plato's work.

Socrates describes the nature of Eros as not only dual but downright antagonistic in nature, the one variant contending with the other, and he declares that he will speak frankly against the Eros that is the opponent of the one that is dwelling in himself ${ }^{17}$. His speech then develops into a rather magisterial lecture about the two conflicting Erotes. Socrates argues in favour of friendly love, whose object is the good soul, and he underlines that this chaste love is no less graced by Aphrodite than the love of the body ${ }^{18}$, and that actually no loving relation worthy of mention can exist in the absence of friendship ${ }^{19}$.

The serious tone adopted by Socrates in his speech contrasts in a striking way to the easy-going, humorous conversation otherwise prevailing in the symposion. And after his speech he apologizes for having spoken more seriously than is appropriate at a drinking-party. It is also noticeable that Socrates directs his outspokenly didactic and rather moralizing speech to Callias, his host, but he does not take offence. Instead he expresses his appreciation, and Lycon, the father of Callias' beloved Autolycus, praises Socrates as a good and noble $\operatorname{man}^{20}$.

Plato's picture of Socrates as able to resist even an Alcibiades' efforts of seduction seems thus to be substantiated by the representation of him by Xenophon. His speech appears to be critical only to pederasty ${ }^{21}$, and this is also incidentally suggested by contrast in the end of the work, when the married guests hurry home to their wives, inspired by the scenic display of the marriage of Dionysus and Ariadne by the young actors. The chaste kind of Eros that Socrates praises as providing the love of souls and which he affirms is the one dwelling in him, this Eros seems in reality to be $\varphi \imath \lambda i ́ \alpha$, friendly love, to judge from how he describes it. As a matter of fact there is no properly erotic atmosphere in Xenophon's Symposium, except precisely in the final theatrical performance, although Xenophon tries to keep up a semblance of a feeling such as in Plato's Symposium. Instead, it is the friendly, good-humoured spirit of $\varphi$ i $\lambda$ í $\alpha$ that prevails throughout, and which Socrates confirms in his speech.

\section{The followers}

The ethos of friendliness, good temper and sense of humour which characterizes Xenophon's Symposium was to determine the nature of the Socratic kind of symposium for the future, as we can observe in Plutarch's convivial works. With his Symposium Xenophon broadened the scope of the

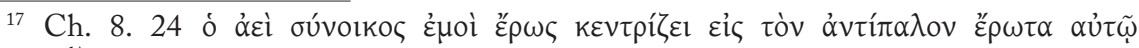
$\pi \alpha \rho \rho \eta \sigma \iota \alpha ́ \zeta \varepsilon \sigma \theta \alpha \iota$.

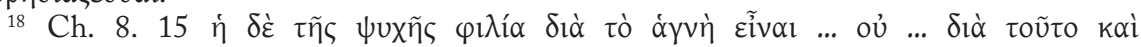

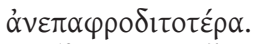

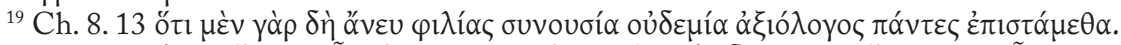

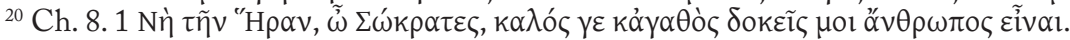

${ }^{21}$ Ch. 8. 32-40. 
newly founded genre. With the good spirits and the easy-going conversation Xenophon added substantially to the foundation of the genre laid by Plato. The greater comprehensibility of the content and the less sophisticated linguistic form may have been what inspired the numerous writers at the time who followed his lead and composed sympotic works. We may suppose that these differed considerably among themselves according to the authors' different interests and preferences. But unfortunately, all of these writings are lost.

Aristotle is known to have written some kind of sympotic work ${ }^{22}$, but our sources provide very scarce information on it; perhaps it bore a resemblance to the scholarly Deipnosophistae of Athenaeus ${ }^{23}$. According to Plutarch, Theophrastus and Aristoxenus also wrote Symposia. He mentions that both treated questions of music in these writings ${ }^{24}$. Epicurus' Symposium is the only work of this genre at that time, on which we have a more detailed information ${ }^{25}$. Plutarch blames him for excluding questions about music and similar inquiries from the drinking-parties and for enjoying instead in vulgar buffooneries ${ }^{26}$. Athenaeus informs us that in the Symposium of Epicurus the guests formed a company of flatterers who praised one another, and he contrasts this with the character of Plato's and Xenophon's works. $\mathrm{He}$ censures the absence of an introduction and a specification of place and time in Epicurus' Symposium, and he criticizes that the subjects discussed are mainly sympotic and he also finds fault with his clumsy literary style ${ }^{27}$. It appears, then, that Epicurus Symposium may have been enacted in his Garden, that his guests all belonged to his circle, and that the conversation was in the main confined to the sympotic sphere.

It is worth noticing that only two Academics, Speusippus and Dion of Alexandria, are given as writers of Symposia, but only by Plutarch who only mentions their names ${ }^{28}$. The absence of any positive information on these texts, and considering that there are contrary indications as to their character, makes it seem questionable whether they really were Symposia at all ${ }^{29}$. Even if the scarcity of information makes our judgement uncertain, then, we may raise the question why there was little or practically no continuation of the true Socratic symposium among Platonists. One would think that it should have been natural for members of the Academy to follow the lead of the founders and add works of their own to the new genre.

${ }^{22}$ D. L. 5.22 (5.1.12). Only one fragment is preserved: Athen. 15.674 F-675 A; cf. Schol. in Theocr. 3.21 p. 122.16 Wendel.

${ }^{23}$ See R. Hirzel I, 1895, pp. 284-5, 346 n. 1; J. Martin, 1931, pp. 204-5.

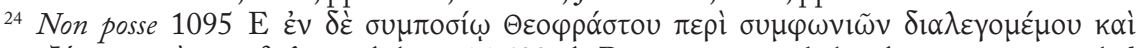

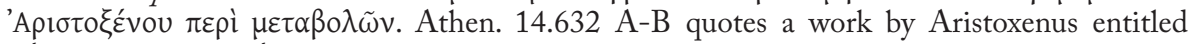

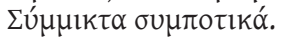

${ }^{25}$ Phld., Rh. 90.27, 96.22, 97.22 Sudhaus.

${ }^{26}$ Non posse 1095 C-D.

${ }^{27}$ Ath. 5.182 A, 186 E, 187 C.

${ }^{28}$ Quaest. conv. $612 \mathrm{DE}$.

${ }^{29}$ See J. Martin, 1931, pp. 162-3, 196-7; S.- T. Teodorsson, 1989, pp. 35-6. 


\section{Non-Socratic sympotic writings}

\section{Persaeus}

Now, a new sort of sympotic writings originated, apparently initiated

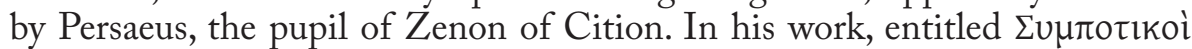

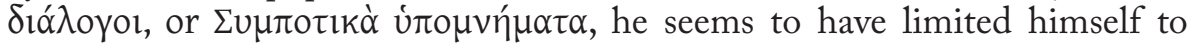
sympotic subjects in a strict sense, and with a strong emphasis on sexual matters at that ${ }^{30}$.

\section{Menippean Symposla}

Not much later, in the third century, Menippus the Cynic appeared as the founder of a new genre, the Cynic satire. Among his works there was also a Symposium. We know of it only thanks to a short mention by Athenaeus in a passage on different kinds of dance ${ }^{31}$. However, although we know so little about Menippus' own sympotic writings, we may infer upon their character from the Symposia and similar texts written by his numerous imitators, Meleager, Lucilius, Varro, Horatius, Petronius, Lucian and Julian the Emperor. This new kind of convivial literature, the so-called Menippean Cynic symposium, differed very much from the classical Socratic one, to say the least. Conversation on philosophic or other serious subjects is absent; instead there are ironic allusions, wrangle and overt verbal attacks, and in the end it may even come to blows. The happenings in Lucian's Symposium are most illustrative of the intentions of the writers of this kind of literature. Their aim is to make fun of and mock at prominent people, not least philosophers, setting out their imperfections and oddities in such a way as to make them appear as caricatures.

The considerable number of writers of this kind of works suggests that this genre was rather popular. Shall we perhaps suppose that the Socratic kind of symposium was not able to keep up with the competition? At any rate, the contrast between the considerable frequency of that genre and the virtual absence of Socratic symposia during about four hundred years, from the late Classical time till Plutarch, calls for an explanation.

\section{Plutarch}

We can take for granted that Plutarch knew the Menippean kind of symposium fairly well. We should of course not think that he had actually read Petronius' Cena Trimalchonis, but it is reasonable to suppose that he had knowledge of its content. Judging from what we know of his personality and

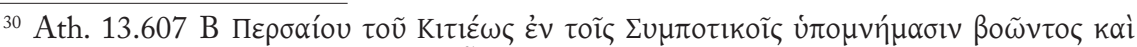

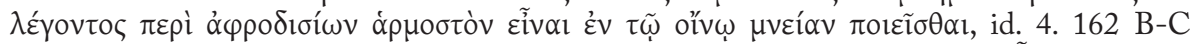

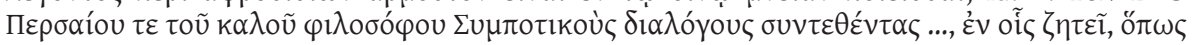

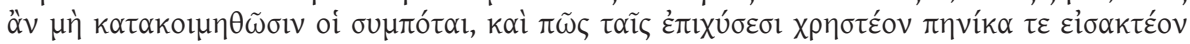

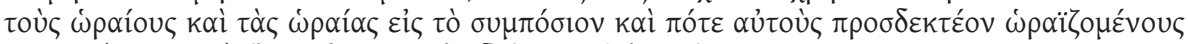

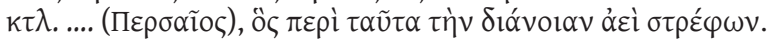

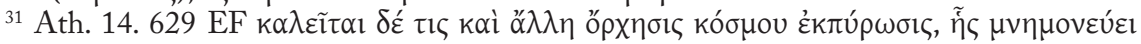

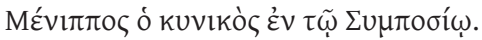


ethical outlook, we may safely assume that he looked with disgust at that sort of feasts and that kind of literature. It therefore appears as probable that his loathing for such depravation was actually his main motive for composing a quite different sort of symposium. It was certainly natural for him to decide upon writing a symposium with participants interested in philosophic questions, and differing among themselves in character and outlook, so as to bring about a varied, interesting conversation. In short, Plutarch wanted to write a Socratic symposium ${ }^{32}$. For his Symposium of the Seven Wise Men he no doubt used Xenophon's Symposium as a model. Plato's extraordinary work did not match his purpose. His choice of the Seven Wise Men as participants at the banquet shows his intention, to compose a symposium that would contain a large range of topics and variegated discussions. The result was a work of very mixed content, and with a distinct aim and direction. Plutarch makes this quite clear from the beginning. He assigns the first two chapters to the declaration of his intention.

The story is well-known: Periander, the tyrant of Corinth, has invited the Seven and many more to a banquet. Three of these, Thales, Neiloxenus of Naucratis and Diocles the narrator, are on their way to the place on foot, since Thales has dismissed the fashionable carriage placed at their disposition by the host. The walk thus affords them the opportunity of free and undisturbed talk. The main topic turns out to be about the despotic rule of kings and tyrants, a rather surprising one for invited guests on their way to a host who is a ruling tyrant. Thales is very outspoken and says that he regards Solon as very wise in refusing to be a tyrant. And he adds that Periander, who is afflicted with the disease of despotism, is actually making fair progress towards recovery now that he is bringing about gatherings with men of sense.

But then it occurs to Thales that it is not appropriate to talk only about what can be demanded of the host. There should also be some preparations on the part of the guests. He then delivers a very Plutarchan speech on how a guest should put his character in order and be prepared to take part in serious or humorous conversations, and to listen and to talk on any topic that happens to be suggested.

With these straightforward preliminaries Plutarch sets the tone for the symposion. Thales, the only one of the Seven who is a philosopher, is the natural mouthpiece of Plutarch. He is to play a prominent part in the conversation, always expressing wise and sensible thoughts, for example when he reproves the young Alexidemus, who angrily complains of having been assigned an ignominious place at table. Thales censures this behaviour, telling him that his complaint means objecting to his neighbour rather than the host. But Plutarch is ironic at his own expense when he makes the young man retort:

"But I observe that you wise men are also eager for being honoured!".

${ }^{32}$ Plu., Quaest. conv. 686 C-D explicitly uses this term to denote a symposion where conversation on topics of philosophic inquiry is essential. 
Plutarch frequently makes use of his sense of humour in the work, thus avoiding the imminent risk of appearing too didactic. Taken as a whole, his Symposium is a well composed mixture of seriousness and pleasantry, perhaps even more well-balanced than that of Xenophon. The merry-maker Aesop tells his fables, but the jesting replies and repartees of the guests contribute more to the humorous and friendly convivial atmosphere. As in Xenophon, seriousness receives a greater weight toward the end, but it is not concentrated to one long speech like that of Socrates in that work ${ }^{33}$. The content of the work as a whole is more varied than in Xenophon.

This is owing to the different number of topics in the two Symposia. There is virtually only one in that of Xenophon, the question of what each is good at and is proud of, whereas in Plutarch we distinguish as many as eight, namely

1. the question of what an absolute ruler should be like,

2. the list of questions of the Ethiopian king, which are seriously answered by Thales,

3. the topic on democratic government,

4. the question of management of a home,

5. the question of the adequate acquisition of property,

6. the discussion on food, drink and diet,

7. the topic of drinking caused by Periander's toast to Chilon, and

8. the telling of wonderful stories about dolphins on the occasion of the rescue of Arion.

Most of these topics give rise to serious utterances and speeches as well as pleasantries. Consequently, the conversation as a whole is more substantial and rich in view-points in Plutarch's Symposium than in that of Xenophon.

As a matter of fact, there is a lot of ingrediences in Plutarch's Symposium that have no correspondence in that of Xenophon or in any other known earlier sympotic work. They are:

1. The long preliminaries with a varied conversation before the banquet.

2. The narrator who remains unknown until the end of the third chapter.

3. The incident with the "monster", the infant centaur.

4. The incident with the guest who leaves in anger.

5. The numerous (Plutarchan) apophthegmata interspersed in the talk.

6. Political questions are discussed over the cups.

7. Women are present during the drinking-party.

8. The extraordinary story of Arion is reported to the company.

On the other hand, we observe that some elements are absent. It is noticeable that entertainment is absent; only a flute-girl plays in connection with the libation. And there is no erotic mood in the company, either a genuinely erotic atmosphere as in Plato's Symposium, or a more or less artificial one as in Xenophon's work. And there is no heavy drinking. When Periander drinks to Chilon in a big cup, this does not lead up to a drinking-bout, but instead to a discussion on questions related to the wine, e.g., Pittacus' law

\footnotetext{
${ }^{33}$ Admittedly, there is also the short radical speech of Antisthenes in Ch. 4.
} 
that prescribed a double penalty for a man who commits an offence when drunk than for a sober man, and it is emphasized that the task of Dionysus is not intoxication and gulping down wine but rather the friendly feeling, the longing and the association one with another. Thus the good-humoured atmosphere is preserved throughout the party, even when delicate political topics are discussed. Periander puts up rather well with listening to critical remarks on despotic rule. Only once (152 B) he sets a hard face. Seeing that, Aesop demonstrates sympathy with him and wisely reproves the critics, and after there has been some talk on other things, the tyrant reenters into the conversation (153 E), showing no resentment any more.

By these means of composition Plutarch succeeds on the one hand to show the natural reaction of the tyrant to the criticism, and then to suggest how irritation can, and should, be toned down. Plutarch simply does not accept bad feelings at a symposion. He gives an expressive proof of his attitude when he tells of how Thales blames the guest who takes offence at the placing at table and leaves before the beginning of the banquet. Plutarch certainly wanted to demonstrate his principle directly at the beginning that uncivil persons have no place at a symposion. It is noticeable that nobody asks the young man to stay.

Indeed, Plutarch does not conceal that he was writing his Symposium with an ethical intent. We may assume that he wanted to lodge a protest against the contemporary deranged convivial behaviour, and presumably his attack was not least directed against Roman drinking-parties. A depressing survey of the hard drinking in the Roman upper classes has been presented by Philip Stadter ${ }^{34}$.

Moreover, looked upon as a literary work it seems likely that Plutarch intended his Symposium to be a counterbalance to the contemporary satirical descriptions of chaotic symposia. It appears that it was the predominating trend at the time to represent exactly these worst drinking-parties in sympotic works. Instead, Plutarch wanted to describe a symposion conducted in good order as an attempt at a revival of the Socratic kind of symposium. His decision to write it may well have been precisely a reaction to Petronius'work, published not much earlier. Plutarch's Symposium cannot be dated with any certainty, but it was most probably written in the 80 ies or 90 ies. In any case, it was written before the Quaestiones convivales ${ }^{35}$.

This work is singular in all respects. Since it is the only one of its kind that is extant, we do not know if Plutarch had any model for it. We know that Didymus Chalcenterus wrote a work that carried the title $\Sigma u \mu \pi o \sigma l \alpha k \alpha$ or $\Sigma v ́ \mu \mu \imath \kappa \tau \alpha^{36}$, but we have no reliable knowledge of its shape. However, to judge from what we know about the content and general nature of this writer's

${ }^{34}$ P. A. Stadter, 1999, pp. 488-9.

${ }^{35}$ See C. P. Jones, 1966, pp. 72-3.

${ }^{36}$ D. L. 5.76 (V 5.6); Clem. Al. Strom. 4. 19. 618 P.; EM. 718.35; St. Byz. 305.1, 314.6, 452.8; Herenn. Philo Ammon. De diff. p. 35 Valck; Et. Gud. 124.2; Eust. 1788.53-54; and see J. Martin, 1931, pp. 172-3. 
overwhelming authorship, of which we have rather scarce fragments, we may suppose that this work was of a scholarly type similar to that of Athenaeus. The fact that Plutarch considered it appropriate to elucidate the difference between

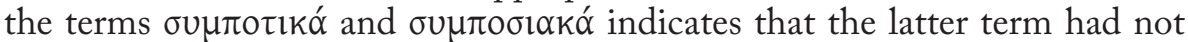
been used before in the sense he uses it. We are thus entitled to assume that with his $\Sigma v \mu \pi \sigma \sigma 1 \alpha k \alpha$ he actually founded a new kind of convivial literature. He presents his program for this kind in the very first talk of the work where he expressly refers to Plato's and Xenophon's Symposia. He declares that in a company of educated men serious philosophic and scientific topics should be allowed to dominate to a large extent. It would seem that such a claim should have been unnecessary, especially for a philosopher, and a Platonist at that. Does it really mean that substantial discussions over the cups were rather uncommon at the drinking-parties of his time?

Plutarch declares that in a company of ordinary, less educated men different kinds of entertainment may be allowed to predominate. But in a mixed company the uneducated persons should keep quiet like mute consonants between sonant vowels. Drinking should be controlled, as it is in the Quaestiones convivales. And there entertainment occurs only as an exception $^{37}$, but it is frequently made the object of discussion, in which certain kinds of music and dancing are expressly condemned ${ }^{38}$. More than anything else Plutarch makes the pantomime the target of his scorn, as in the outburst at the very end of the work.

Strong commitment to the amelioration of the symposion was then obviously a main incentive for Plutarch to write his Symposium of the Seven Wise Men and thus to revive the Socratic symposium. But this ethic incentive is no less obvious in the Quaestiones convivales. This being the case, it seems to me that the cause of origin of this work must be reconsidered. I will certainly not call in question that Plutarch actually composed it on the request of Sosius Senecio, but I think we should pose this question: Is it actually reasonable to think that it was only because of Sosius' desire that Plutarch decided to compose and publish his recollections of drinking-parties, either preserved in his own memory or in some kind of notes? I feel doubts about that. It is obvious that large parts of the Quaestiones convivales are based on Plutarch's own memories. Now, if he had actually made some notes of the main features of his symposia, as to place, time, occasion, participants, subjects discussed etc., should we imagine that he made these notes only for his private use, as a kind of diary, with no intention to use the material for publication? I venture to say that this is highly improbable. I dare to suggest that Plutarch was actually prepared to publish at least part of the material, and that he communicated his plans to his old companion at many symposia, Sosius Senecio. It will have been quite natural for Plutarch to do that, and for Sosius gladly to commend the publication.

What I argue, then, is that it was Plutarch himself who got the idea of writing a series of short symposiac texts based in part on his own

\footnotetext{
${ }^{37}$ As in Quaest. conv. VII 5.

${ }^{38}$ E.g., Quaest. conv. VII 8.
} 
remembrances and notes and in addition on collections of Problemata and Zetemata and a great number of other sources. The result was a pioneer work of a new kind within the genre of symposium. Presumably, Plutarch got a vision of this new kind of convivial writing from his own experiences of symposia characterized by conversation on subjects of value over the cups in a friendly environment.

It appears as probable, then, that Plutarch produced his convivial writings in two separate steps. First he decided to write a truly Socratic symposium with the aim to revive this kind. The result was the Septem Sapientium convivium. Then, in the course of time, he got the idea of a new kind of sympotic writing, inspired by his own experiences, and with the aim to propagate these to wider circles of

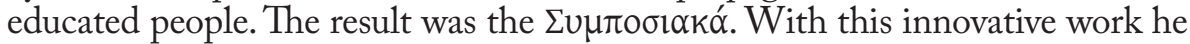
actually laid the basis for the possible development of a new branch within the genre of symposium. But unfortunately, his work was not followed by others of similar kind. The writings of Athenaeus, Macrobius, Apuleius or Gellius have a quite different character and are not properly symposiac writings.

And in addition the satiric Menippean tradition was not broken, as Plutarch might have hoped, but instead was continued not much later by Lucian, and then by Julian the Emperor.

The place of Plutarch in the history of the genre of symposium therefore stands out as virtually exceptional. His convivial works are singular for three reasons:

1. The revival of the Socratic symposium,

2. The founding of the new genre of $\Sigma u \mu \pi$ o $1 \alpha$ kó aiming at a close combination of education and amusement, and

3. The ethical purpose displayed in both of these convivial writings.

\section{WORKS CITED}

Babut, D. "Painture et dépassement de la réalité dans le Banquet de Platon", REA 82, 1980, 5-29.

Bremmer, J. N., “Adolescents, symposion, and pederasty”, in O. Murray, 1990, pp. 135-48.

Frazier, F. "Aimer, boire et chanter chez les Grecs: La littérature au banquet d'Homère à Athénée", in Bacchanales, Cabiers du Gita, 13, 2000, 65105.

Hirzel, R., Der Dialog I-II, Leipzig, 1895.

Jones, C.P., “Towards a chronology of Plutarch's works", JRS, 56 (1966) $70-4$

Lissarrague, F., Un flot d'images. Une esthetique du banquet grec, Paris, 1987. (English translation: The Aesthetics of the Greek Banquet: Images of Wine and Ritual, Princeton 1990.) 
Martin, J., Symposion. Die Geschichte einer literarischen Form, Paderborn, 1931.

Montes Cala, J. G. et al. (eds.), Plutarco, Dioniso y el vino. Actas del VI Simposio Español sobre Plutarco (Cádiz, 14-16 de Mayo, 1998), Madrid, 1999.

Murray, O., Sympotica. A Symposium on the Symposion, Oxford, 1990.

Murray. O. \& Tecuşan, M. (eds.), In Vino Veritas, London, 1995.

Rösler, W., "Wine and truth in the Greek Symposion" in O. Murray \& M. Tecuşan (eds.), 1995, pp. 106-12.

Stadter, P. A., "Drinking, Table Talk, and Plutarch's contemporaries”, in J. G. Montes Cala et Al. (eds.), 1999, pp. 481-99.

Tecuşan, M., “Logos sympotikos” in O. Murray, 1990, pp. 238-60.

Teodorsson, S.-T., A Commentary on Plutarch's Table Talks I, Göteborg, 1989. A Commentary on Plutarch's Table Talks II, Göteborg, 1990. 